\title{
Right Ventricular Hypertrophy
}

National Cancer Institute

\section{Source}

National Cancer Institute. Right Ventricular Hypertrophy. NCI Thesaurus. Code C50734.

Enlargement or overg rowth of the myocardium of the right ventricle, due chronic pressure overload. 